УДК 37.015.311:81243

DOI: https://doi.org/10.35619/iiu.v0i9.4

Горобець Інна

кандидат психологічних наук, доцент кафедри української та іноземної лінгвістики

Луцького національного технічного університету.

м.Луцьк, Україна

ORCID: 0000-0002-6873-513X

e-mail: mamchurinna@ukr.net

\title{
ДІАЛОГІЧНІСТЬ МИСЛЕННЯ В ПРОЦЕСІ ФОРМУВАННЯ ОСОБИСТІСНОЇ КУЛЬТУРИ ВИКЛАДАЧА IHOЗЕМНОÏ МОВИ
}

\begin{abstract}
Анотація. У статті проаналізовано особистісну культуру викладача іноземної мови в професійній діяльності педагогів у психологічній літературі; охарактеризовано основні чинники діалогічного мислення; обгрунтовано розвиток Школи діалогу культур у психологічній науці. У вимогах сучасних підходів до вивчення іноземних мов наголошено на важливості не знань про мову, а на досконалому володінні мовним матеріалом, комунікативними уміннями, здатності використовувати ці знання і уміння для вирішення конкретних комунікативних завдань у ситуаціях спілкування. Досліджено, що сучасний фахівець отримує нову фахову інформацію через іноземні джерела. Вивчення іноземних мов сприяє реалізації таких напрямів професійної діяльності, як ознайомлення 3 новими технологіями, науковими гіпотезами і тенденціями, видатними інноваціями в галузі техніки; встановлення контактів 3 іноземними фірмами, підприємствами, навчальними закладами; підвищення рівня професійної компетенції фахівців. Володіння іноземною мовою вже $є$ не ознакою престижу, а потребою сучасного фахівця.
\end{abstract}

Ключові слова: особистісна культура, діалогічне мислення, діалогокультурологічний підхід, викладач іноземної мови, школа діалогу культур.

Постановка проблеми. Формування особистісної культури викладача відбувається в найбільш важливих сферах життєдіяльності, причому в тих сферах, де людина почувається автором, господарем, суб'єктом власного життя. У зв'язку із цим для викладача стає важливою міра суб'єктності, зафіксована у вигляді соціально-психологічних настановлень (фіксованих соціальних настановлень або атитюдів) щодо себе самого.

Варто зазначити особистісний ресурс викладача як простір реального i можливого викладання іноземної мови. При цьому сфера викладання, у якій викладач настановлений щодо себе самого як до об'єкта, не є закрита, а залишається ділянкою його потенційного розвитку, простором його можливого. Оскільки активність викладача у сфері викладання іноземної мови здійснюється на різних рівнях - від простого життєзабезпечення до реалізації життєвого покликання.

Аналіз останніх досліджень 3 проблеми. Аналіз наукової літератури показує, що проблема формування особистісної культури викладача іноземної мови в контексті діалогічного мислення знаходить своє розв'язання у психологічній науці через розкриття концептуальних положень на предмет 
вузівської підготовки спеціаліста (Л. С. Возняк, Л. В. Кондрашова, М. Н. Корнєв, С. Д. Максименко, М. І. Пірен, В. Т. Циба, Г. Й. Юркевич та ін.), прогнозування професійної діяльності випускника вузу (Л. П. Овсянецька, І. Д. Пасічник, Н. І. Пов’якель, С. В. Терещук, Ю. Л. Трофімов, В. С. Пілецький та ін.), місця і ролі викладача в навчальному процесі (В. П. Казміренко, Л. М. Карамушка, Н. Л. Коломінський, О. Ю. Кошинець, Г. В. Ложкін, Н. О. Михальчук, Л. Е. Орбан-Лембрик, І. М. Семенов, В. В. Третьяченко, В. М. Шепель та ін.). У численних працях (М. М. Бахтін, О. О. Бодальов, Г. Я. Буш, М. С. Каган, 3. С. Карпенко, О. М. Коропецька, М. Н. Корнєв, В. П. Москалець, М. В. Савчин, В. А. Семіченко, Т. М. Титаренко, А. І. Хараш, Т. К. Чмут, Т. Д. Щербан, Я. Яноушек та ін.) по-різному розуміється роль i місце спілкування у становленні та розвитку особистості.

Метою статті $\epsilon$ формування особистісної культури викладача іноземної мови в контексті діалогічного мислення, що відображається на успішному засвоєнні навчальних дисциплін, зокрема іноземної мови.

Виклад основного матеріалу дослідження. Викладач, який працює у вищій школі, беручи до уваги Школу діалогу культур, опиниться перед необхідністю повністю змінити традиційний підхід до процесу виховання та навчання. Школа діалогу культур працює за експериментальною програмою В. С. Біблера (Библер, 1990, с.43). Навчальний процес на занятті повинен бути майстерно ініційований викладачем. На занятті під час бесіди, дискусії, диспуту розгортається діалог, в якому за допомогою правильно підібраних оригінальних текстів беруть участь представники основних періодів європейської культури. Правильно організований на заняттях діалог не припиняється у свідомості учасників і після закінчення заняття, що підтверджують написані студентами твори про той чи інший предмет обговорення. Іноземна мова в умовах співіснування народів світу стає засобом міжкультурного спілкування, отже, процес професійного навчання має відповідати вимогам часу. До таких вимог належить передусім набуття студентом відповідного рівня професійної компетентності, тобто здатності використовувати набуті знання, навички та вміння як у фаховій, так і в інших сферах діяльності (М. К. Колкова). Компетентність, як зазначає вказаний науковець та іï співавтори, базується на володінні певними компетенціями, вмінні їх реалізувати, удосконалювати в процесі навчальної та трудової діяльності (Яценко, 1987, с.25).

На заняттях студент має опановувати різні кути зору на світ, ціннісні системи, діяльності, які уособлюють певні культурні світи (за В. С. Біблером): античний, середньовічний, новочасний, сучасний. У процесі дискусій передбачаються діалоги різних персонажів: студентів одного курсу, студентів і викладача, студентів різних курсів між собою, студента і тексту культури (з автором і героєм, або від імені автора чи героя твору). Будь-який елемент змісту курсу предмета отримує своє «культурне» специфічне тлумачення, постає як такий, що постійно розвивається, переосмислюється, поглиблюється. 3 іншого боку, різні елементи змісту курсу можуть органічно поєднуватися i навіть перетікати одне в одне. I тільки за таких умов побудови вищої школи студенти будуть творчими особистостями, здатними до самостійного мислення, а спосіб їхнього життя визначиться насолодою спілкування, мислення творчості. Дискусії на заняттях, побудовані за принципами діалогокультурологічного підходу, навчають, аби не тільки в теоретичному спорі, а й 
у будь-якій справі в повсякденному житті партнер зі спілкування виступав би як той, хто «дивиться інакше», як опонент, і саме завдяки цьому був цінним i необхідним для інших співрозмовників. За таких умов для кожної людини встає природно необхідною інша людина, «як джерело і співмислення, i співчуття, i розуміння; і незгоди, й іншого погляду, й несподіваного запитання» (Михальчук, 2004, с.22).

Отже, розглядаючи та аналізуючи основні психологічні умови ефективної дискусії на заняттях іноземної мови термінами «монолог» та «діалог», ми позначаємо не так форми спілкування, як принципи його побудови. За монологічного підходу викладач виступає носієм незаперечної істини, монологічне спілкування застосовується тільки для того, щоб «привести» студента до цієї істини. За діалогічного підходу студент має право на власну думку, власну позицію. Викладач поважає позицію студента; якщо це необхідно, він може вносити корективи вже у свою власну позицію.

Лев Силенко (2005, с. 730) визначає мислення як духовну діяльність, поведінку життя людини. Людина така, яке в неї мислення. «Говоріть щось, хочу знати, які ви є».

Мислення і почуття не відділені одне від одного. У мисленні людини живе іiі Минуле, Сучасне і Майбутнє. Людина успадкувала Минуле від предків, дідів, батьків. Не маючи Минулого, вона не могла б орієнтуватися в Сучасному.

Мислення - слово. Немає такого Мислення, яке б нікому не належало. Мислення поєднане 3 людиною так, як поєднане дерево 3 коренем: хворіє корінь - хворіє дерево; хворіють нерви - хворіє людина (ії мислення). Є вислів: «Мислю - значить живу». Людина, яка живе, щоб тільки жити, має неповноцінне життя.

Людина, яка знає, що знає і знає, що не знає, - розумна. Знання - освіта, а вільне осмислення знання - достоїнство, а переоцінка знання - розум. Людина розумна знає, що правильне Мислення вільне, дисципліноване, толерантне, спокійне, передбачливе, блаженне, наполегливе, послідовне, чесне, зосереджене, бадьоре, ясне-зрозуміле, цілеспрямоване, діалогічне.

При аналізі діалогічного мислення в структурі професійної підготовки через принцип діяльності найбільш продуктивним шляхом його реалізації $\epsilon$ шлях, де викладач розглядається як цілісна особистість з притаманною йому системою діяльностей, як суб'єкт предметної діяльності, специфічним чином поєднуючий іiі з діяльністю інших людей, вступаючий з студентами в систему спільної діяльності - співробітництва в тій чи іншій його формі.,

Науковці виокремлюють певні чинники, що визначають позитивну мотивацію, задоволеність від спільної дії: усвідомлення мети, досягнення успіхів у роботі, впевненість у собі, позитивна оцінка своїх можливостей, прояв інтересу до діяльності, позитивне ставлення до діяльності, позитивна оцінка групи i свого місця в ній. Викладач включає у сферу впливу i взаємовпливу студентів, робить їх співучасниками обміну інформацією, та діями 3 метою підвищення процесу професійної підготовки як на когнітивному, так і на особистісному рівнях. Взаємодія в навчально-виховному процесі має свою специфіку, яка полягає у: а) суб'єктності, особистісності кожного учасника навчально-виховного процесу вищої школи; б) значущій залежності результату впливу суб'єктів взаємодії один на одного від ступеня гуманізації концепції викладача; в) багаторівневій побудові системи 
професійної підготовки, яка зумовлює опосередкованість, віддаленість кінцевого результату від безпосередніх продуктів діяльності спеціалістів (управлінських рішень тощо).

Слід зазначити, що спілкування іноземною мовою виступає інтегруючою ланкою, центральною складовою в контексті діалогічного мислення (навчально-виховний процес - спілкування іноземною мовою - особистість, яка сприймає діалогічне мислення). Тільки через спілкування як один із різновидів людської діяльності, як обмін почуттями, переживаннями, як специфічну форму соціального зв'язку, комунікативно-сполучну роль в утвердженні і підтвердженні з боку інших, як потребу особистості можливою $\epsilon$ передача i засвоєння знань, формування професійних вмінь та навичок, розвиток професійного світосприйняття викладача і поряд з цим задоволеність i ефективний розвиток глибинних сторін його особистості; потребовомотиваційної сфери, когнітивної, соціальної, сфери особистісної культури і самовдосконалення (Мамчур, 2010, с.173).

Проведений аналіз наукової літератури дозволяє стверджувати, що спілкування іноземною мовою в контексті діалогічного мислення як психологічна проблема, вивчене недостатньо. Водночас, на нашу думку, спілкування виступає інтегруючою ланкою професійної підготовки спеціалістів, що забезпечує успішне функціювання навчально-дидактичного, емоційно-афективного, потребово-мотиваційного особистісного розвитку та самовдосконалення блоків професійної підготовки викладачів. Тільки через спілкування як один із різновидів діяльності, обмін почуттями, переживаннями, специфічну форму соціального зв'язку, потребу особистості, комунікативно-сполучну роль в утвердженні і підтвердженні з боку інших можлива передача знань i засвоєння знань, формування вмінь i навичок, формування особистісної культури викладача під час освітньо-виховного процесу. Діалогічність мислення передбачає орієнтацію людини на кілька рішень, 3-поміж яких вона обирає найкраще. Мислення, спрямоване на пошук різних варіантів розв'язання, називають дивергентним (Библер, 1990, с.39). Протилежний різновид мислення - конвергентне - орієнтоване на вибір єдиної відповіді. У пошуку особливе значення має дивергентне мислення. Різні смислові позиції конкурують між собою за право бути реалізованим, а це дозволяє їх краще осмислити, глибше зрозуміти.

Проявом діалогічності мислення як умови творчості є його варіант, що розгортається у спільній діяльності людей. За цих умов перед кожним виникає необхідність логічно осмислити хід розв'язання, аби зрозуміло й аргументовано представити його іншим. Перші варіанти об'єктивації рішення часто недосконалі, 3 суб'єктивними домішками. Логічне обгрунтування рішення, що зумовлене мотивами передачі інформації іншим, значно полегшується та якісно покращується в умовах колективу.

Важливий вплив на процес творчості спричиняє й критика з боку колег. Хід пошуку розв'язання стає обгрунтованішим та аргументованішим, зменшується кількість помилок, зростає реалістичність задумів. Особливо важливою критика $€$ на етапі розумової діяльності, яка підготовлює до практичної реалізації. Наприклад, відомий норвезький фізик Нільс Бор працював разом з високоерудованими й критично мислячими асистентами К. Хансеном, й В. Гейзенбергом. Завдяки дискусіям між ними народились «принципи доповнення» Н. Бора та співвідношення невизначеностей В. 
Гейзенберга. За принципом доповнення, для сприймання цілісності досліджуваного об'єкту або процесу, необхідно співвідносити різні ракурси його аналізу.

У творчому колективі доцільно поєднувати працівників, які можуть виконувати ролі генератора ідей, критика, скептика. В експерименті створювались три однорідних групи 3 генераторів, ерудитів та критиків. Четверта група об'єднала учасників з різними ролями. Вчені останньої групи

використали найменше часу й виробили оптимальне рішення (Мамчур, 2010, c.33).

Інтереси розвитку економіки сьогодення та культури нашої України, зростання соціальної ролі викладача вимагають всебічного стимулювання i розвитку потенційних можливостей кожної людини (Яценко, 1987, с.33). У нашому сьогоденні, коли здійснюється активний пошук та оновлення усіх сфер суспільства, гостро відчувається потреба в людях, які володіють мистецтвом створювати здоровий психологічний клімат в колективі, вміють слухати i взаємодіяти 3 людьми, запобігати виникненню конфліктів та вирішувати різноманітні ситуації.

Висновки і перспективи подальших розвідок. Якісне володіння іноземними мовами $€$ необхідною умовою для входження у відкритий інформаційний простір i суспільство, для спілкування, для полегшення процесу соціологізації в сучасному ринковому середовищі. Однією із головних завдань модернізації освіти $є$ забезпечення знань на рівні функціональної грамотності принаймні з однієї іноземної мови. Упродовж багатьох років навчальні програми та стандарти в галузі викладання іноземних мов зводили ці знання лише до володіння читанням на рівні міжнародних стандартів функціональної грамотності, і при цьому значно менше уваги приділялося усному мовленню, писемному мовленню та аудіюванню. У нових підходах до вивчення іноземних мов наголошується на важливості не знань про мову, а досконалому володінні мовним матеріалом, комунікативними уміннями, здатності використовувати ці знання і уміння для вирішення конкретних комунікативних завдань у ситуаціях спілкування.

\section{СПИСОК ВИКОРИСТАНИХ ДЖЕРЕЛ:}

Библер, В. (1990). Нравственность. Культура. Современность. Москва: Знание. 320с.

Яценко, Т. (1987). Социально-психологическое обучение в подготовке будущих учителей. Київ: Вища школа. 112 с.

Михальчук, Н. (2004). Навчальні дискусї. Рівне: РДГУ. 124 с.

Силенко, Л. (2005). Мага Віра: Святе письмо. Велике світло волі. Співвідночення віри, науки, філософії, історії. Львів. $831 \mathrm{c.}$

Мамчур, I. (2010). Особливості здатності до спілкування іноземною мовою у майбутніх вчителів. Луцьк: «ВАТ Волинська обласна друкарня». 244 с.

\section{REFERENCES:}

Bibler, V. (1990). Nravstvennost. Kultura. Sovremennost [Moral. Culture. Contemporary]. Moskva: Znanye. 320 s. [in Russian]

Yatsenko, T. (1987) Sotsyalno-psykholohycheskoe obuchenye $v$ podhotovke budushchykh uchytelei [Social and Psychological Learning in Training of Future Teachers]. Kyiv: Vyshcha shkola. 112 s. [in Ukrainian] 
Mykhalchuk, N. (2004). Navchalni dyskusii [Teaching Discussions]. Rivne: RDHU. 124 s. [in Ukrainian].

Sylenko, L. (2005). Maha Vira: Sviate pysmo. Velyke svitlo voli. Spivvidnoshennia viry, nauky, filosofii, istorii [Maha Vira: Holy Writing. Large Light of Will. Correlation of Will, Science, Philosophy, History]. Lviv. 831 s. [in Ukrainian]

Mamchur, I. (2010). Osoblyvosti zdatnosti do spilkuvannia inozemnoiu movoiu u maibutnikh vchyteliv [Peculiarities of Capable for the Speaking of Foreign Language in the Future Teachers]. Lutsk: "VAT Volynska oblasna drukarnia". 244 s. [in Ukrainian]

\title{
THE DIALOGICS OF INTELLECTION IN PROCESS OF THE FORMATION OF PERSONAL CULTURE OF A FOREIGN LANGUAGE TEACHER
}

\author{
Inna Horobets \\ $\mathrm{PhD}$ in Psychology, \\ Associate Professor at the Department of Ukrainian and Foreign Linguistics, \\ Lutsk National Technical University, \\ Lutsk, Ukraine \\ ORCID: 0000-0002-6873-513X \\ e-mail: mamchurinna@ukr.net
}

\begin{abstract}
Good knowledge of foreign languages is a prerequisite for entering the open information space and society, for communication, to facilitate the process of sociologization in the modern market environment. One of the main tasks of the modernization of education is to provide knowledge of at least one foreign language at the level of functional literacy. For many years, curricula and standards in the field of teaching foreign languages have reduced this knowledge to reading skills at the level of international standards of functional literacy, while much less attention was paid to oral speech, writing and listening.

In this article, the personal culture of a foreign language teacher in the professional activity of educators in the psychological literature is analyzed; the main factors of the dialogical thinking are characterized; the development of the School of Dialogue of Cultures in psychological science is proved. Within the conditions of a new approach to the study of foreign languages, not the importance of knowledge about the language is emphasized, but the perfect possession of linguistic material, communicative skills, the ability to use this knowledge and skills to solve specific communication tasks in communicative situations. The learning of a foreign language contributes to the realization of such areas of professional activity as the introduction of new technologies, scientific hypotheses and trends, innovations in the fields of technology; establishment of contacts with foreign firms, and educational institutions; increase the level of professional competence of specialists. Knowledge of a foreign language is no longer a sign of prestige, but a need of a modern specialist. This fact implies the abilities of a foreign language teacher to combine students' skills of general foreign language and their professional knowledge in a particular field of science and technology.
\end{abstract}

Key words: personal culture, dialogical thinking, dialogical and cultural way, foreign language teacher, School of Dialogue of Cultures

Стаття надійшла до редакиіï 20.03.2019 p. 